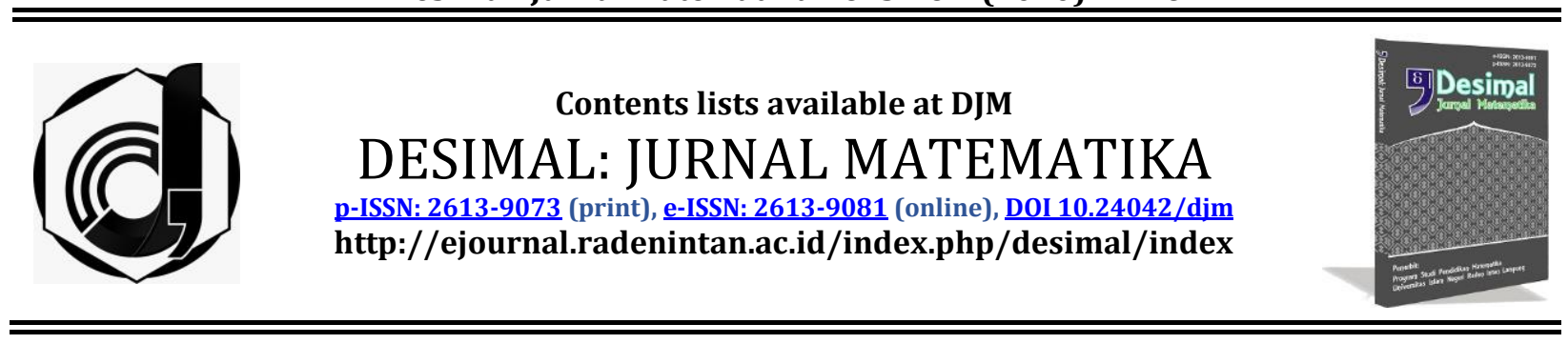

\title{
Analysis of Mathematical Problem Solving Capabilities : Impact of Improve and Osborn Learning Models on Management Education
}

\author{
Munifah ${ }^{1, *}$, Windi septiyani², Indah tri rahayu ${ }^{2}$, Rahmi Ramadhani ${ }^{3}$, Hasan Said Tortop ${ }^{4}$ \\ ${ }^{1}$ Institut Agama Islam Negeri Kediri, Indonesia \\ 2 Universitas Islam Negeri Raden Intan Lampung, Indonesia \\ ${ }^{3}$ Universitas Potensi Utama, Indonesia \\ ${ }^{4}$ Genc Bilge Counsulting \& Publishing, Istanbul, Turkey
}

\section{ARTICLE INFO \\ Article History \\ Received : 20-08-2019 \\ Revised : :12-12-2019 \\ Accepted : 02-01-2020 \\ Published : 26-01-2020}

Keywords:

Improve;

Osborn;

Mathematical Problem Solving

Ability.

*Correspondence: E-mail:

munifahkediri@gmail.com

Doi:

$\underline{10.24042 / d j m . v 3 i 1.5335}$

\begin{abstract}
Objectives The ability to solve problems is to gain knowledge and motivation in the problem solving process of students. The researcher used the Improve and Osborn learning models to improve problem solving skills. The Improve and Osborn learning models emphasize the development of optimal mathematical skills and generate new ideas in the process of problem solving. This research is used to see the impact of the Improve learning model and Osborn learning model which is better in mathematical problem solving abilities. This research uses the Quasy Experimental Design method. Hypothesis testing uses an independent sample test. The conclusion of the study is the mathematical problem solving ability of students who use the Improve learning model is better than the mathematical problem solving abilities of students who use the Osborn learning model.
\end{abstract}

\section{INTRODUCTION}

Mathematical learning model is very important to be used to improve students' abilities (Nasution, Eka, Rangkuti, \& Al-washliyah, 2019). Models that can be used to improve students' abilities, for example, the IMPROVE learning model and the OSBORN learning model. One of the goals of the learning model is to have students' mathematical problem solving abilities (Purba, Surya, Syahputra, \& Masalah, 2018). Mathematics learning must always be improved, 
because as the development of science (Huda, Tsani, Syazali, Umam, \& Jermsittiparsert, 2020).

To help improve and develop problem solving skills, it must use the right learning model, because in the IMPROVE learning model and the OSBORN learning model, it is considered appropriate to improve students' mathematical problem solving abilities (Nurafifah, Nurlaelah, \& Usdiyana, 2016). Students who use IMPROVE learning are expected to be more active in improving problem solving skills (Rosiani, Anggo, \& Sudia, 2019). The IMPROVE learning model has a good effect compared to conventional learning on students' problem solving (Huda et al., 2019). While the OSBORN learning model enhances imagination in the creative problem-solving process that leads to an integrative understanding of concepts is a major component in OSBORN learning. The quality of ideas produced by the OSBORN model can focus attention. The aim is to build students 'thinking processes to be more active so that they can increase students' understanding and increase self-confidence (Haeruman, Rahayu, \& Ambarwati, 2017).

Problem solving ability as an aspect in mathematics (Akbar, Hamid, Bernard, \& Sugandi, 2018). Problem solving ability is considered important because it is a basic solution in learning mathematics (Purba et al., 2018). In fact the problem solving ability of students is still quite low (Rahmawati et al., 2019). There are several learning models that can be applied to develop mathematical problem solving abilities (Putra, 2018).

Based on previous research, research on problem solving skills using the SAVI, PBL, cooperative discourse, means-End learning model has been carried out (Gunawan et al., 2019; Lintang \& Wardani, 2017; Prabowo, 2016; Putri,
Suryani, \& Jufri, 2019; Tristiyanti \& Afriansyah, 2016; Ulvah \& Afriansyah, 2016). There are also studies that use the IMPROVE learning model on the ability to understand concepts, think critically, and study outcomes (Aningsih \& Sari, 2013; Liberna, 2015; Millah, Purnomo, \& Faizin, 2017; Mujib, 2016; Risma Yunita \& Menrisal Menrisal, 2017; Suciati, 2018). Previous researchers also examined the OSBORN learning model on the ability to think creatively, learning outcomes, learning achievement (Alfianitasari \& Hidayati, 2018; Ardana, 2019; Aziz \& Wijayanti, 2015; Diantari \& Hasan, 2016; Liyawati \& Sulistyaningrum, 2019; Nurafifah et al., 2016; Sari, Rosmeri, \& Izzati, 2019)

Previous studies have also been conducted on the IMPROVE model and the OSBORN model on students' mathematical problem solving abilities (Jayanti, Ardana, \& Suryawan, 2019; Oktavianti, Farida, \& Putra, 2018). Based on this research the researcher is interested in comparing the IMPROVE learning model and the OSBORN learning model with the problem solving ability of students (Diani et al., 2019), because in previous studies no one has examined which is better between the IMPROVE learning model and the OSBORN learning model.

\section{METHOD}

The research method can be said as a way to get data with specific uses and purposes. This research is an experimental research with quasy experimental design, this design has a control group but does not fully function to control the external variables that influence the implementation of the experiment. The research design used is post-only control design. This study has two variables, namely the independent variable and the dependent variable. The independent variables in this study are the IMPROVE 
Desimal, 3 (1), 2020 - 19

Munifah, Windi Septiyani, Indah Tri Rahayu, Rahmi Ramadhani, Hasan Said Tortop

and OSBORN learning models. While the dependent variable in this study is the ability to solve mathematical problems (Wicaksono, 2018). The study population was all junior high school students. The researcher used random sampling techniques in sampling. The sample taken is two classes, the first class is the first experimental class using the IMPROVE learning model. The second class is the second experimental class using the OSBORN learning model.

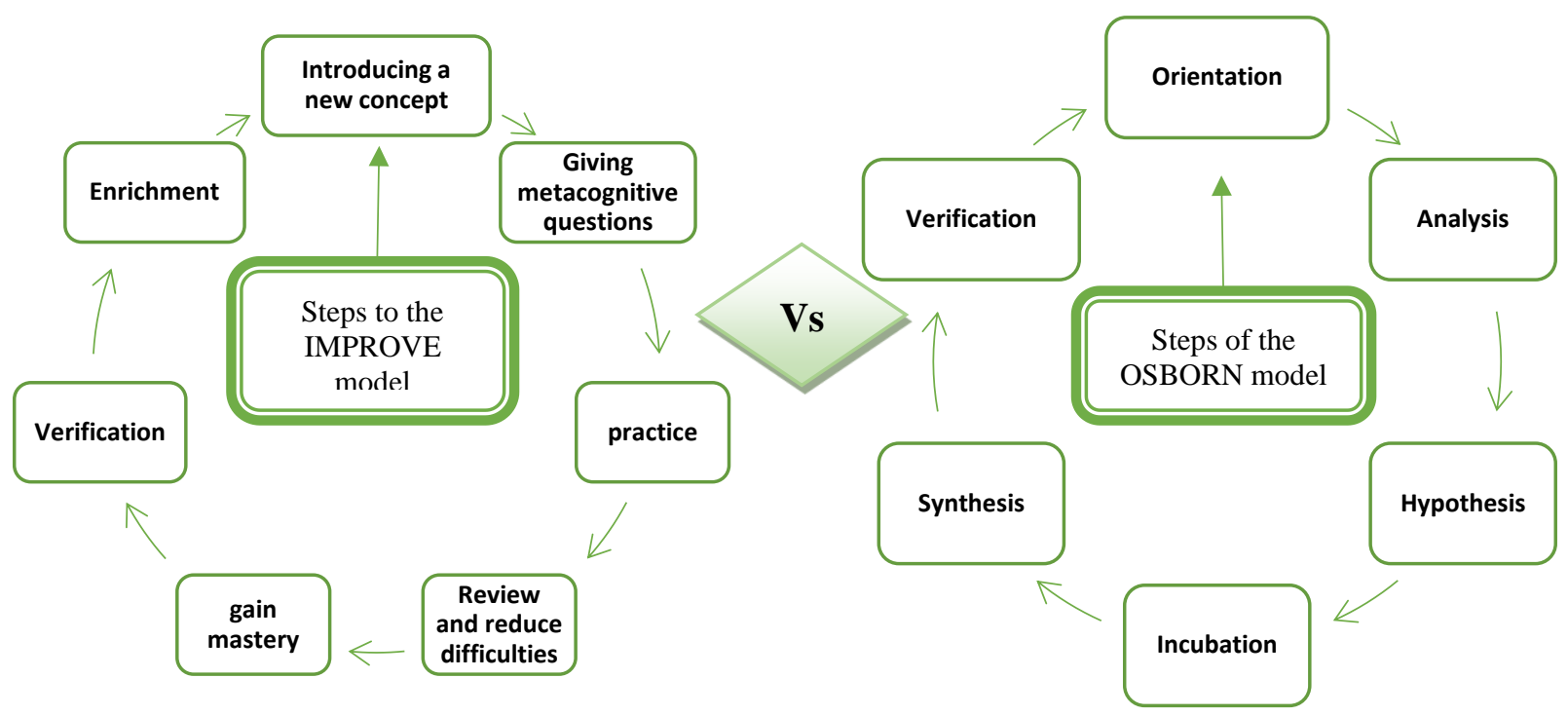

Figure 1. Research Design

Researchers use written tests in data collection techniques in the form of problem descriptions to measure students' mathematical problem solving abilities (Indra Puspita Dewi, Wisna Ariawan, \& Gita, 2019). Stages before the test instrument is used in carrying out research among them, compiling material that will be used in the questions, making a lattice of questions, compiling questions and their keys and conducting test questions about the test. The instrument was tested on the participation of students to determine the validity, reliability, level of difficulty, and distinguishing problems. After obtaining the test result data the test is then analyzed descriptively to describe the data in general. Researchers conduct normality tests and homogeneity tests as a pre-requisite test to test the hypothesis. The hypothesis test that will be carried out in this research is the $t$ test.

\section{RESULTS AND DISCUSSION}

Based on the description above, the following is the descriptive test results of the test data for mathematical problem solving abilities.

Table 1. Descriptive Test Results for Test Data for Mathematical Problem Solving Ability

\begin{tabular}{cccccccc}
\hline Model & Mean & Median & Varians & $\begin{array}{c}\text { Standard } \\
\text { deviation }\end{array}$ & Min & Max & Range \\
\hline IMPROVE & 74.9500 & 74.0000 & 88.366 & 9.40031 & 60.00 & 92.00 & 32.00 \\
OSBORN & 65.2000 & 62.0000 & 105.853 & 10.28847 & 52.00 & 90.00 & 38.00 \\
\hline
\end{tabular}


Based on Table 1, it can be seen about the data overview in general, that the average value for the IMPROVE learning model is 74.9500, while the average value for the OSBORN learning model is 65.2000. IMPROVE model obtained the middle value, the lowest and highest value is $74.0000,60.00$ and 92.00 . Then the acquisition value of 88366 variance and the standard deviation of 9,40031 . The OSBORN model is obtained the middle value, the lowest and highest values are $62.0000,52.00$ and 90.00 . Then the acquisition value of 105,853 variance and the standard deviation of 10.28847 .

Based on the results of the data analysis, the researcher will conduct a $\mathrm{T}$ test, before the $\mathrm{T}$ test the researcher conducts a normality and homogeneity test as a pre-requisite test. Normality test is used to find out whether the data is normally distributed or not, while the homogeneity test is used to find out whether the data is homogeneous or not. This pre-requisite test uses a significance level $\alpha=0.05$.

$H_{0}=$ Data is normally distributed

$H_{1}=$ Data not normally distributed

Conclusion if $p$ value $>\alpha$ SO $H_{0}$ accepted, rejected $H_{1}$, while if $p$ value $<\alpha$ so $H_{0}$ rejected, accepted $H_{1}$. Following are the results of the normality test for mathematical problem solving abilities.

Tabel 2. Hasil Uji Normalitas Kemampuan Pemecahan Masalah Matematis

\begin{tabular}{lrrrrrr}
\multirow{2}{*}{ Model } & \multicolumn{2}{c}{ Kolmogorov-Smirnova } & \multicolumn{3}{c}{ Shapiro-Wilk } \\
& Statistic & \multicolumn{1}{c}{ Df } & P value $^{*}$ Statistic & \multicolumn{1}{c}{ Df } & P value \\
\hline IMPROVE & .136 & 20 & $.200^{*}$ & .954 & 20 & .427 \\
OSBORN & .117 & 20 & $.200^{*}$ & .969 & 20 & .738 \\
\hline
\end{tabular}

Based on Table 2 the normality test results with a significant level $\alpha=0.05$ shows that the application of the OSBORN learning model and the IMPROVE learning model to the mathematical problem solving ability shows the $\mathrm{p}$ value of the OSBORN learning model is 0.200 and the IMPROVE learning model is 0.200 for the Kolmogorov-Smirnov learning probability. Because the values of $p$ value $>\alpha$, both data are normally distributed.

Homogeneity test with hypothesis $\mathrm{H}_{0}=$ Homogeneous data, $\mathrm{H}_{1}=$ Data are not homogeneous. $\mathrm{H}_{0}$ is accepted if $\mathrm{p}$ value $>\alpha$. The following table homogeneity test results:

Table 3. Homogeneity Test Results

\begin{tabular}{cccc}
\hline $\begin{array}{c}\text { Levene } \\
\text { Statistic }\end{array}$ & df1 & df2 & P value \\
\hline .494 & 1 & 38 & .487 \\
\hline
\end{tabular}

Based on Table 3 homogeneity test results with a significant level of 0.05 , it can be seen that the $p$ value is 0.487 greater than 0.05 , so it can be concluded that both homogeneous data. After pre- test, the normality test and homogeneity test, the data is normally distributed and homogeneous, so the researcher will conduct an independent samples test. 
Desimal, 3 (1), 2020 - 21

Munifah, Windi Septiyani, Indah Tri Rahayu, Rahmi Ramadhani, Hasan Said Tortop

Table 4. Independent samples Test

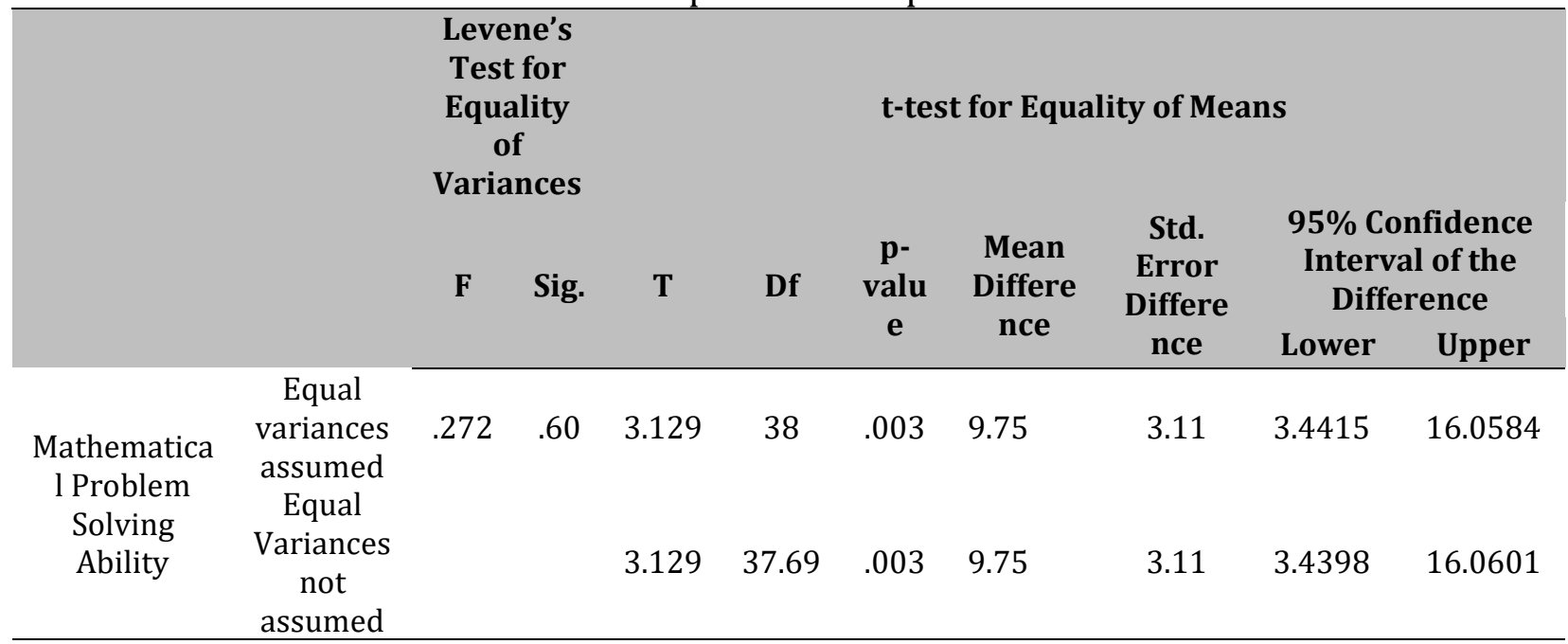

Based on Table 4 independent sample test results test whether the two models have the same average.

$H_{0}=$ both models have the same problem solving average.

$H_{1}=$ Both models do not have the same problem solving average.

T count (3.129) > t table is 1.72472 so $H_{0}$ rejected. So both models do not have the same average problem solving. In the descriptive table the average for the IMPROVE learning model is 74.9500, while for the OSBORN learning model is 65.2000. It means that the IMPROVE learning model has an average value higher than the OSBORN learning model.

The IMPROVE learning model is an abbreviation of all steps in teaching, namely: Introducing the new concepts (introducing new concepts), Metacognitive questioning (giving metacognitive questions), Practicing (exercises), Reviewing and Reducing Difficulties (reviewing and reducing difficulties), Obtaining mastery (gaining mastery), Verification (verification), Enrichment (enrichment). While the steps of the OSBORN learning model, namely: Orientation (providing information and motivation), Analysis (solving a problem), Hypothesis (provisional estimation), completion process, Synthesis (merging of results), Verification (the process of determining the truth).

From the steps of the learning model there are differences between the two, in the IMPROVE model there is Enrichment or enrichment, which is to provide opportunities for students who have not mastered the material to deepen the mastery of the material optimally, while in the OSBOR model only until verification is the process of determining the truth of a problem. From these differences it can be seen that the IMPROVE learning model is better than the OSBORN learning model. This is in line with the results of previous studies in which the IMPROVE model is better than conventional models in improving problem solving abilities (Jayanti et al., 2019). Besides being able to improve the problem-solving ability of the IMPROVE model, it can also improve critical thinking skills, understanding concepts and learning outcomes (Liberna, 2015; Millah et al., 2017; Mujib, 2016; Risma Yunita \& Menrisal Menrisal, 2017). On the other hand the OSBORN learning model is also better than the conventional model in improving problem solving skills. Besides 
being able to improve problem solving the OSBORN model can also improve learning achievement, understanding concepts and creative thinking (Alfianitasari \& Hidayati, 2018; Ardana, 2019; Aziz \& Wijayanti, 2015; Liyawati \& Sulistyaningrum, 2019; Sari et al., 2019). However in terms of problem solving ability IMPROVE learning models have a better impact than OSBORN learning models.

\section{CONCLUSIONS AND SUGGESTIONS}

Based on the whole series, the researcher can conclude that there is an influence of the OSBORN learning model and the IMPROVE learning model on the students' mathematical problem solving abilities. However, according to the data that has been obtained shows that the IMPROVE learning model is better than the OSBORN learning model for students' mathematical problem solving abilities. The IMPROVE learning model encourages students to be active and get to know a new concept in problem solving, so that educational goals can be achieved to the maximum. Based on research that has been done is expected to be a reference for further research. Further research is suggested, emphasizing the activeness of students. learning by forming groups does not look conducive but if it is managed well, it will make students more active and can be effective learning models. Added interesting media so that students are more interested in participating in learning activities.

\section{REFERENCES}

Akbar, P., Hamid, A., Bernard, M., \& Sugandi, A. I. (2018). Analisis kemampuan pemecahan masalah dan disposisi matematik siswa kelas xi sma putra juang dalam materi peluang. Jurnal Cendekia: Jurnal Pendidikan Matematika, 2(1), 144153.

Alfianitasari, S., \& Hidayati, N. (2018). Penerapan Model Pembelajaran Osborn Untuk. (22), 102-111.

Aningsih, A., \& Sari, riska puspita. (2013). Penerapan Model Pembelajaran Improve Dalam Meningkatkan Pemahaman Konsep Pada Mata Pelajaran Matematika Siswa Kelas Iv Sd Negeri Pengasinan I Bekasi. Journal of Chemical Information and Modeling, 53(9), 1689-1699. https://doi.org/10.1017/CB097811 07415324.004

Ardana, I. M. (2019). Efektivitas Model Pembelajaran Osborn Dalam. Jurnal Pendidikan Dan Pembelajaran Matematika Indonesia, 8(1), 20-28.

Aziz, M. A., \& Wijayanti, K. (2015). Kemampuan Berpikir Kreatif Dan Self-Efficacy Siswa Kelas X Smk Teuku Umar Semarang Dengan Model Pembelajaran Osborn. Unnes Journal of Mathematics Education., 4(3), 231237.

https://doi.org/10.15294/ujme.v4i3. 9050

Diani, R., Irwandani, I., Al-Hijrah, A.-H., Yetri, Y., Fujiani, D., Hartati, N. S., \& Umam, R. (2019). Physics Learning through Active Learning Based Interactive Conceptual Instructions (ALBICI) to Improve Critical Thinking Ability. Jurnal Penelitian Dan Pembelajaran IPA, 5(1), 48. https://doi.org/10.30870/jppi.v5i1. 3469

Diantari, M., \& Hasan, M. (2016). Penerapan Model Pembelajaran Osborn Untuk Meningkatkan Hasil Belajar Siswa Pada Materi Koloid Di Kelas Xi Ipa 1 Sman 1 Indrapuri. Ilmiah Mahasiswa Jurusan Pendidikan Kimia (JIMPK), 3(1), 22-31. 
Gunawan, G., Fitriana, U., Kushendri, K., Fatimah, F., Mustika, C. Z., \& Hidayat, W. (2019). Kemampuan Pemecahan Masalah Matematis Siswa Smp Melalui Pemberian Perlakuan Pembelajaran. Journal on Education, 1(3), 1-8.

Haeruman, L. D., Rahayu, W., \& Ambarwati, L. (2017). Pengaruh model discovery learning terhadap peningkatan kemampuan berpikir kritis matematis dan self-confidence ditinjau dari kemampuan awal matematis siswa SMA di Bogor Timur. JPPM (Jurnal Penelitian Dan Pembelajaran Matematika), 10(2).

Huda, S., Sholikhakh, R. A., Bina, N. S., Lestari, F., Habibi, B., \& Suharso, P. (2019). Effect of Application Smart Circuit Learning Media to Mathematics Learning Outcomes: A Case Study of Islamic School Students. Journal for the Education of Gifted Young Scientists, 7(September), 699715.

https://doi.org/https://doi.org/10.1 7478/jegys.597053

Huda, S., Tsani, I., Syazali, M., Umam, R., \& Jermsittiparsert, K. (2020). The management of educational system using three law Auguste Comte: A case of Islamic schools. Management Science Letters, 10(3). https://doi.org/10.5267/j.msl.2019. 9.018

Indra Puspita Dewi, K., Wisna Ariawan, I. P., \& Gita, I. N. (2019). Analisis Kesalahan Pemecahan Masalah Matematika Siswa Kelas Xi Sma Negeri 1 Tabanan. Jurnal Pendidikan Matematika Undiksha, 10(2), 43. https://doi.org/10.23887/jjpm.v10i 2.19917

Jayanti, N. P. S., Ardana, I. M., \& Suryawan, I. P. P. (2019). Pengaruh Model Pembelajaran Improve Berbantuan
Masalah Terbuka Terhadap Kemampuan Pemecahan Masalah Matematika Siswa Kelas Viii Smp Laboratorium Undiksha. Jurnal Pendidikan Matematika Undiksha, $X(2), 2599-2600$.

Liberna, H. (2015). Peningkatan Kemampuan Berpikir Kritis Matematis Siswa Melalui Penggunaan Metode Improve pada Materi Sistem Persamaan Linear Dua Variabel. Formatif: Jurnal Ilmiah Pendidikan MIPA, 2(23), 190-197.

Lintang, A. C., \& Wardani, S. (2017). PBL dengan APM untuk Meningkatkan Kemampuan Pemecahan Masalah dan Sikap Percaya Diri. Journal of Primary Education, 6(1), 27-34.

Liyawati, I. A., \& Sulistyaningrum, H. (2019). Jurnal Riset Pembelajaran Matematika Penerapan Model Pembelajaran Osborn Dengan Media. 1(April), 7-10.

Millah, S. I., Purnomo, B., \& Faizin, A. (2017). Matematika Materi Spldv Dengan Menerapkan Model. Jurnal Ilmiah : SOULMATH, 5(2), 42-50.

Mujib. (2016). Mengembangkan Kemampuan Berfikir Kritis Melalui Metode Pembelajaran Improve. Aljabar: Jurnal Pendidikan Matematika, 7(2), 167-180.

Nasution, A. S., Eka, D., Rangkuti, S., \& Alwashliyah, U. M. N. (2019). Pengembangan Bahan Ajar Matematika Berbasis Masalah Pengetahuan manusia tentang matematika memiliki peran penting dalam peradaban manusia, sehingga matematika merupakan bidang studi yang selalu diajarkan di setiap jenjang pendidikan Esensi pembelajaran $m$. (2), 608-617.

Nurafifah, L., Nurlaelah, E., \& Usdiyana, D. (2016). Model Pembelajaran Osborn Untuk Meningkatkan Kemampuan 
Desimal, 3 (1), 2020 - 24

Munifah, Windi Septiyani, Indah Tri Rahayu, Rahmi Ramadhani, Hasan Said Tortop

Pemecahan Masalah Matematis Siswa. M A T H L I N E: Jurnal Matematika Dan Pendidikan Matematika, 1(2), 93-102. https://doi.org/10.31943/mathline. v1i2.21

Oktavianti, S., Farida, F., \& Putra, F. G. (2018). Implementasi Model Osborn Dengan Teknik Mnemonic Melalui Teori Konstruktivisme Terhadap Kemampuan Pemecahan Masalah Matematis. MaPan, 6(1), 94-103. https://doi.org/10.24252/mapan.20 18v6n1a9

Prabowo, A. (2016). Keefektifan Model Pembelajaran Means-Ends Analysis Pada Kemampuan Pemecahan Masalah Siswa Materi Segiempat. Unnes Journal of Mathematics Education., 5(2), 119-123. https://doi.org/10.15294/ujme.v5i2. 11400

Purba, E. N., Surya, E., Syahputra, E., \& Masalah, P. (2018). Pemecahan Masalah Pada Materi Fpb Dan Kpk. Jurnal Pendidikan Matematika, (2015).

Putra, F. ganda. (2018). Pengaruh Model Pembelajaran Reflektif dengan Pendekatan Matematika Realistik Bernuansa Keislaman terhadap Kemampuan Komunikasi Matematis. Journal of Chemical Information and Modeling, 53(9), 1689-1699. https://doi.org/10.1017/CB097811 07415324.004

Putri, R. S., Suryani, M., \& Jufri, L. H. (2019). Pengaruh Penerapan Model Problem Based Learning terhadap Kemampuan Pemecahan Masalah Matematika Siswa. Mosharafa: Jurnal Pendidikan Matematika, 8(2), 331340.

https://doi.org/10.31980/mosharaf a.v8i2.471

Rahmawati, R., Lestari, F., Umam, R., Islam,
U., Raden, N., Bandar, I., \& Lampung, U. M. (2019). Analysis of the Effectiveness of Learning in the Use of Learning Modules Against Student Learning Outcomes. Desimal: Jurnal Matematika, 2(3), 233-240.

Risma Yunita, \& Menrisal Menrisal. (2017). Pengaruh Penerapan Metode Pembelajaran Improve Terhadap Hasil Belajar Siswa Mata Pelajaran Teknologi Informasi dan Komunikasi (TIK) (Studi Kasus Kelas XI SMAN 12 Padang). Jurnal Kajian Bimbingan Dan Konseling., 2(1), 9-22.

Rosiani, Anggo, M., \& Sudia, M. (2019). Pengaruh Pembelajaran Berbasis Masalah Kontekstual dengan Pendekatan Metakognisi terhadap Kemampuan Pemecahan Masalah Matematika Siswa Kelas VIII SMP. Jurnal Pembelajaran Berpikir Matematika, 1(1), 71-82.

Sari, M., Rosmeri, L., \& Izzati, N. (2019). Penerapan Pembelajaran Osborn untuk Kemampuan Berpikir Kreatif pada Materi Bilangan Pecahan Siswa Kelas VII SMP Negeri 6 Tanjungpinang Maya. Pendidikan Matematika, 10(3), 1-7.

Suciati, D. (2018). Perbandingan Kemampuan Pemahaman Konsep Matematis Melalui Model Pembelajaran Improve Dan Model Pembelajaran Langsung Pada Siswa Kelas VIII Smp Negeri 30 Muaro Jambi. Journal of Chemical Information and Modeling, 53(9), 1689-1699. https://doi.org/10.1017/CB097811 07415324.004

Tristiyanti, T., \& Afriansyah, E. A. (2016). Kemampuan Pemecahan Masalah Matematis Siswa Melalui Model Pembelajaran Kooperatif Tipe Diskursus Multi Representasi Dan Reciprocal Learning (Studi Penelitian 
Desimal, 3 (1), 2020 - 25

Munifah, Windi Septiyani, Indah Tri Rahayu, Rahmi Ramadhani, Hasan Said Tortop

di MTs. Mathlaul Ulum Garut). Jurnal

Silogisme: Kajian Ilmu Matematika

Dan Pembelajarannya, 1(2), 4-14.

Ulvah, S., \& Afriansyah, E. A. (2016). Kemampuan Pemecahan Masalah Matematis Siswa ditinjau melalui Model Pembelajaran SAVI dan Konvensional. Jurnal Riset Pendidikan, 2(2), 142-153.

Wicaksono, teguh cahyanto. (2018). The influence of expedition couriers, informations systems and consumer complaints on the expedition with service quality as a mediating variable to increase customer satisfaction ( at pt jne express brach semarang ). International academy journal Web of Scholar, 1-13. https://doi.org/10.31435/rsglobal_ wos/12062018/5781 
Desimal, 3 (1), 2020 - 26

Munifah, Windi Septiyani, Indah Tri Rahayu, Rahmi Ramadhani, Hasan Said Tortop 